\title{
Integrating China's agricultural economy into the global market Measuring distortions in China's agricultural sector
}

\author{
Jikun Huang, Yu Liu, Will Martin and Scott Rozelle
}

Although there has long been an interest in the agricultural economy, it is quite surprising to many observers that China's agricultural sector has a record that is impressive in many dimensions. Growth rates of gross domestic product (GDP), agricultural gross value added and food per capita increased substantially since the early 1980s. Indeed, agricultural performance in the past two to three decades was more impressive than in any other country in Asia. Markets have boomed and the structure of agriculture has shifted fundamentally. Despite having the largest population in the world and high income growth (which has had a wrenching change on the nation's consumption bundle), China has, since the early 1980s, been a net exporter of food in all but one year.

While the performance of the economy is well documented, there is less understanding about the environment within which this growth occurred. In particular, there have not been many studies of the economic environment that created some of the incentives for producers. In the past, there has been work on the nature of the distortions of China's agricultural economy (for example, Huang et al. 2004; OECD 2005; Orden et al. 2007). Unfortunately, previous studies have been only partial. For example, Huang et al. (2004) looked only at the distortions in a single year; Orden et al. (2007) examined only six years between 1995 and 2001. The OECD (2005) examined only a small set of commodities and made a number of simplifying assumptions about some of the most important commodities, such as pork meat and poultry. Perhaps because of the partial nature of these studies, they reached a number of different conclusions. 
The purpose of this chapter is to examine the extent of the Chinese agricultural sector's integration into the world market by estimations of indicators of direct and indirect interventions by the Chinese government in agriculture from 1981 to 2005. The main part of our analysis examines the differences between international prices and domestic wholesale prices at the border (nominal rates of assistance or NRA). We also consider distortions in the domestic economy by examining the differences between farm-gate and border prices (NRAf).

The wide scope of the objectives, as with other studies, necessitates certain limitations. First, the absence of data precludes us from examining the entire agricultural sector. Instead, we examine commodities that account for nearly two-thirds of the gross value output in all of the study years. Second, although we are able to judge from the price trends and from an understanding of domestic marketing and pricing and trade policy reforms the source of the shifts in the distortions of the agricultural economy, we cannot identify the exact source of changes. Also, although we use our revised exchange rate series to calculate what we believe to be the correct values at which we convert international values into currency-which is useful for making comparisons with prices in China's domestic economy-we do not analyse the effect of these assumptions. This is done elsewhere (Martin et al. 2006).

In the next section, we discuss our quantitative approach and sources of data. The results of the distortion analysis are presented in the third section, while the final section offers conclusions.

\section{Methodology and data sources}

We have utilised the approach specified in Anderson et al. (2006), which is based broadly on comparisons between domestic and international prices. During the reform era, these price comparisons provided indicators of the incentives for production, consumption and trade, and the income transfers associated with interventions.

Our approach creates essentially two measures of distortions for each major commodity in the agricultural economy. The first measures in our analysis are the NRA, which are used to compare the prices of commodities in the domestic economy (at the port) with the international prices of commodities at the border (that is, 'c.i.f.' in the port for importable goods; 'f.o.b.' in the port for exportable ones). The quality adjustments on the border prices were made before we estimated the NRA. Conceptually, with the NRA, we are trying to measure the extent of the distortions due to tariffs, exchange rate distortions and other non-tariff barriers-at the border. 
Because of barriers within the domestic economy, the extent of protection (or lack of protection) that is afforded by trade policies might not be the same as the real rate of protection to farmers. Since we have independent observations on the prices obtained by farmers in local markets, we are able to estimate the nominal rate of assistance at the farm level, taking into account border distortions and distortions affecting farmer returns (NRAf). NRAf are calculated after allowing for quality adjustment, tax or subsidies, transport, storage and handling costs in moving commodities from the farm to the wholesale level. Differences between NRA and NRAf arise from subsidy or transfer payments that cause the prices received by farmers to differ from what they would receive under competitive internal market conditions.

While NRA (and NRAf) measure only differences in output prices, there could also be distortions on the input side. To capture these, it is possible to provide measures to take into account direct subsidies and differences between the international prices of inputs and the prices that farmers pay for these inputs. While these forms of protection (or taxation) are important in many countries - and particularly in Organisation for Economic Co-operation and Development (OECD) countries-we find that they are generally relatively small, so we focus on the NRA and NRAf measures when examining distortions to producers.

Exchange rate distortions present particular measurement problems and require detailed analysis if price comparison-based measures are not to be misleading. The assumption and methods that were used to generate our exchange rate series are in Table A7.1. For documentation of our complete domestic and international price series, see Martin et al. (2006).

In compiling our data, we had to make choices on the coverage of the commodities. We have included 11 commodities: rice, wheat, maize, soybeans, cotton, pork, milk, poultry, fruit (using apples as a representative product), vegetables (using tomatoes as a representative product) and sugar (sugarbeet and sugar-cane). During the study period, these commodities accounted for between 75 per cent (in the late 1980s) and 60 per cent (during the early 2000s) of the total value of agricultural output in China. Because decisions on production and consumption in China's domestic market prices were being allowed to respond to domestic prices only gradually, and because we do not have access to reliable data on the secondary market exchange rates before 1988, we focus on data for the period beginning in 1980 .

The data used in our study come from a number of sources, depending on the time period of analysis and the commodity. Commodity balance data (production, utilisation, trade and others) are from the Centre for Chinese Agricultural Policy's CAPSiM database, which are mainly from the Ministry of 
Agriculture (production), National Bureau of Statistics of China (consumption and others) and the Ministry of Commerce (trade). Domestic prices are from several different ministries. Specifically, farm-gate output prices come from the cost-of-production surveys conducted by the National Development and Reform Commission (NDRC). Wholesale and retail prices for most products are from the Center for Price Monitoring, the NDRC, the Ministry of Agriculture (various years [b]) and the Department of Rural Survey under the National Bureau of Statistics of China. Where wholesale and retail prices for some commodities in some years were not available, price margins from farmgate to wholesale and retail were estimated. Much of the data on margins, transportation costs and other transaction costs are from an extensive set of surveys by Huang and Rozelle during the 1990s and the early 2000s, which served also to establish which commodity price series provided appropriate bases for price comparisons. Some of this was reported previously in Rozelle et al. (2000) and Huang et al. (2004), which provided information on substantial quality differences between some imported and domestic commodities and resulting biases in price comparisons as a measure of protection. For more recent years, survey teams from the Center for Chinese Agricultural Policy interviewed traders in 10 cities throughout China in 2006. The complete data series are in the appendices of Huang et al. (2007).

The international price data ('f.o.b.' and 'c.i.f.') for all commodities except milk are the unit values of the exports or imports with adjustments for quality. These data are from the Ministry of Commerce and China's Customs Administration. For the border price of milk, because no import prices for milk are available, we use the farm-gate price of milk in New Zealand, adjusted by international transportation and insurance rates, to create a series for the international price of milk (c.i.f.), which we refer to as the 'reference price'.

\section{Results}

The role of domestic price and marketing policies

Before examining the role of distortions at the border, it is useful to examine the relationship between the available domestic price series for farm and retail prices for the major grain crops (Table 7.1). The importance (and role) of China's domestic price and marketing policy for rice and wheat (two of the three largest crops in China) can be seen by comparing the state-set urban retail price and the state-set rural farm-gate procurement price with the rural retail price (a free-market price) before 1993, when the urban grain rationing system was formally abolished. Until 1993, urban retail grain prices were generally substantially below the price on the free market in rural areas, despite the costs 


\section{Table 7.1 Rural retail, urban retail and farm-gate sales prices of rice and wheat in China, 1980-2005 (yuan per tonne in real 2005 prices)}

\begin{tabular}{lrcc}
\hline & $1980-93$ & $1994-2001$ & $2002-05$ \\
Rice (in milled rice equivalent) & 1,375 & 1,889 & 1,939 \\
$\quad$ Farm-gate price & 2,069 & 2,145 & 2,112 \\
$\quad$ Rural retail price & 989 & 2,144 & 2,112 \\
$\quad$ Urban retail price & & & \\
Wheat & 1,126 & 1,305 & 1,268 \\
$\quad$ Farm-gate price & 1,700 & 1,433 & 1,325 \\
Rural retail price & 920 & 1,433 & 1,325 \\
Urban retail price & & & \\
\hline
\end{tabular}

Note: We use the years of 1993 and 2001 as time-division points because the former is the year the grain ration policy ended in urban areas and the latter is the year before China joined the World Trade Organization.

Sources: Calculated by the authors based on various sources.

associated with transferring grain to urban areas. This was a consequence of a procurement price system designed to provide urban residents with relatively inexpensive food. Only urban residents could buy grain at these low prices and only with ration coupons that were available in limited quantities.

The marketing and procurement system could have been the source of additional distortions. The relatively low selling price of grain at the farm-gate shows that China's food system in the 1980s was set up to transfer income from rural to urban areas (Table 7.1, Column 1). The amount that farmers received for the mandatory deliveries was far below the free-market price. There is, however, some question about the effects on incentives for production and consumption given the infra-marginal nature of many of these transfers (Sicular 1988). This is because after the mid 1980s, farmers were able to sell additional amounts at higher market prices once they had met their obligation to deliver a fixed-quota quantity at the low purchasing price. If a farmer sold more grain than was required by his or her delivery quota-and the above-quota price was determined by market forces - there could have been less of a distortion. Ultimately, however, even such policies are not fully decoupled from incentives, with seemingly infra-marginal transfers away from rural households, for instance, giving their members an incentive to move out of agriculture. These linkages have been shown by Wang et al. (1999). Therefore, the distortions 
created by domestic marketing and procurement systems could have affected incentives relative to international prices.

From 1994, however, changes to China's domestic marketing and procurement system appear to have eliminated this additional layer of regulation for producers of rice and wheat (Table 7.1, Columns 2 and 3). In the early 1990s, the urban price began to rise above the farm-gate price; urban and rural retail prices also came much closer together (Huang et al. 2007). This reflects the phasing out of the implicit taxation of farmers through the grain procurement system. The gap between urban and rural retail prices essentially disappeared after 1994 (Table 7.1), and the gap between the rural retail price and the farm price declined-possibly suggesting an improvement in marketing efficiency (Park et al. 2002). With the disappearance of the distortions from the marketing and procurement system, the remaining distortions after the mid 1990s reflect only trade policies and not trade and domestic policies.

Nominal rates of assistance for China's main agricultural commodities

All NRA and NRAf are computed at adjusted exchange rates (the estimated equilibrium exchange rates; Table A7.1), since we believe this measure is the right one to use to calculate the true rate of protection. In Martin et al. (2006), we report how the measures of distortions vary when using official and adjusted exchange rates.

Distortions to the grain economy before the mid 1990s. The distortions to the rice economy of China in the 1980s and early 1990s were characterised by two important features (Table 7.2, Row 1). First, the NRA of rice-an exportable commodity-was negative between 1980 and 1993. Averaging -23 per cent, the negative NRA show that China was highly competitive in international rice markets during these years. Trade policy, however, kept exporters from shipping large quantities of rice onto world markets and kept the free-market price of rice in China's port cities below the world price. This demonstrates clearly China's commitment to keeping domestic prices low. Even if there had been no other distortions in the rice economy, producers would have faced prices below world market prices.

The second feature demonstrates how domestic marketing and procurement placed a greater tax on farmers and insulated the domestic price of rice from the world market price even if trade policy had been liberalised (Table 7.2, Rows 1 and 4). Because of China's marketing policy, which lasted through the mid 1990s, the state's artificially low procurement price kept the price received by farmers systematically below the free-market price of rice, as seen by the NRAf. Because of this, the tax on rice farmers averaged -42 per cent. Rice producers 


\section{Table 7.2 Nominal rates of assistance (NRA) and nominal rates of assistance for farmers (NRAf) in the cereal sector in China, 1980-2005 (per cent)}

\begin{tabular}{lccc}
\hline & $1980-93$ & $1994-2001$ & $2002-05$ \\
NRA & & & -6 \\
Rice & -23 & -4 & - \\
Wheat & 47 & 7 & 16 \\
Maize & -1 & -8 & -9 \\
NRAf & & 24 & 1 \\
Rice & -42 & 6 & 11 \\
Wheat & 10 & & \\
Maize & -28 & & \\
\hline
\end{tabular}

Source: Authors' estimations.

were among the most heavily taxed farmers in China, given the large share of the crop's sown area and large negative rates of protection. Importantly, our analysis shows how the state used trade and procurement policy to tax its rice farmers.

The NRA measures show that trade policy offered high rates of protection for wheat farmers in China between 1980 and the mid 1990s (Table 7.1, Rows 2 and 5). Between 1980 and 1993, the free-market price of wheat in China's port cities was 47 per cent higher than the international price (c.i.f., China's port cities). Unlike rice, which China produced competitively during the 1980s, wheat producers - who have been shown to produce at a higher cost than many producers in other countries (Huang and Ma 2000)-received strong protection from trade policy. This policy on its own, unlike that for rice, would not be consistent with providing inexpensive food for consumers. It would, however, be consistent with a policy of food self-sufficiency, since it would encourage greater production by keeping out imports and keeping domestic prices high.

Domestic marketing policies, however, were working in the opposite direction to trade policies. The trends of the NRAf show how the forced deliveries of wheat quotas insulated farmers from the high rates of protection (Table 7.2, Row 5). Although there was still positive protection for wheat farmers in most years between 1980 and 1994, the rates were lower (averaging about 10 per cent). These figures—along with those for rice-show that at least for China's 
staple food crops, the government was not trying to use prices to encourage food security.

The story of maize is a mixture of those for rice and wheat (Table 7.2, Rows 3 and 6). Considering Row 3, trade policy was providing very little protection for maize in the period 1980-93, with an average of -1 per cent. Procurement policy, as in the case of rice and wheat, depressed the price of maize for China's farmers. Measured at the farm-gate level, maize farmers were taxed by 28 per cent in the period 1980-93.

Distortions to the grain economy after the mid 1990s. Our distortions analysis shows that, after 1994, China's international trade and domestic marketing policies changed strikingly (Table 7.2, Columns 2 and 3). It is apparent from the way the differences in the estimates of NRA and NRAf narrow that China's reformers were able to eliminate the procurement policies that had been taxing rice, wheat and maize farmers (either by reducing the tax imposed by trade policy, as in the case of rice, or reducing protection, as in the case of wheat). In another work, Huang et al. (2006) show that the elimination of the procurement quota contributed significantly to a reduction in the implicit tax burden shouldered by farmers.

The liberalisation of domestic markets in the mid 1990s was accompanied by a liberalisation of trade policy - at least in the case of China's major food grains such as rice and wheat. After the mid 1990s, the taxation and subsidisation of rice and wheat clearly were being phased out, as the NRA for rice rose steadily (became less negative) and those for wheat fell. Likely in part in preparation for accession to the WTO, China's leaders liberalised trade for the main food grains to such an extent that between 1995 and 2001 most of the protection for crops was eliminated. Since 2001, the NRA for rice and wheat have been close to zero.

Interestingly, the case of maize is a little different than that for other crops (Table 7.2, Row 3). While NRA moved towards zero in the case of maize, in a number of years after 2000, the NRA for maize were positive (not shown by the average figures in Table 7.2). This indicates that at least in some years national leaders have been protecting maize producers. In part, as discussed in Rozelle and Huang (2004), this could be due to lobbying from Jilin Province, which has been successful in gaining protection for the producers of its most important crop.

Edible oils and cotton. The biggest difference between the analysis of distortions of grain crops and cash crops (at least for soybean and cotton) is that domestic marketing policy has historically played less of a role in incentive distortion. Although in some counties in China there was a procurement delivery 
quota for soybean producers, it was not as widespread as that for grain (in many counties, soybeans were not procured by the state system). In addition, the implicit tax on soybeans in places in which soybean quotas were collected was lower than that for the staple grain crops; there is little difference between the graphs for NRA and NRAf (Huang et al. 2007). The same is true for cotton: except in the mid 1990s, free-market procurement of cotton by private traders was not allowed. When reform finally came to the cotton industry in the mid 1990s, leaders did not move to a two-tier pricing system, but instead allowed for private and commercialised government cotton procurement stations. As a result, the measures of distortion for the NRA and NRAf of cotton are nearly the same (Huang et al. 2007). In fact, the same is true for all the other commodities (livestock, horticulture, milk and sugar). As a result, the discussion in the rest of this section-for all three periods-focuses on trade policy.

The trends in the NRA after 1995 show the strong commitment to trade liberalisation for soybeans (Table 7.3, Row 1). Beginning in the late 1990s and continuing through to 2005, protection for soybeans fell from about 25 per cent to about 10 per cent. This decreasing protection should not, in fact, be surprising given the integration of China into world soybean markets and the monotonic rise in imports (which exceeded 25 million tonnes in 2005). The story of soybeans-and the fall in protection and almost full liberalisation-stands in sharp contrast with that of maize, which enjoyed increasing protection.

The distortion analysis for cotton, in some senses, produces results similar to that for rice (Table 7.2, Row 2). The combination of trade and monopoly procurement policies kept domestic cotton prices lower than world market prices in the 1980s and early 1990s. It appears that China's planners were taxing cotton farmers to supply emerging textile industries with relatively inexpensive raw materials. It is no wonder-with such high implicit taxes on cotton-that

\section{Table 7.3 Nominal rates of assistance for farmers (NRAf) for soybean, cotton and sugar crops in China, 1980-2005 (per cent)}

$\begin{array}{lccc} & 1980-93 & 1994-2001 & 2002-05 \\ \text { Soybean } & \text { n.a. } & 24 & 12 \\ \text { Cotton } & -31 & -6 & -1 \\ \text { Sugar crops } & 33 & 28 & 23\end{array}$

Note: The figures for sugar crops are the sugar output weighted average of sugar-cane and sugar-beet.

Source: Authors' estimations. 
the lack interest from many suppliers, and serious insect problems, led to stagnation and even decreases in the number of areas sown with cotton in many regions (National Bureau of Statistics various years (a)).

After 1994, however, with the liberalisation of most domestic markets and somewhat increased trade liberalisation, there clearly was a shift in the level of distortions faced by cotton producers (Table 7.2, Row 2). Although there were years in which there was fluctuations, since the mid 1990s, the NRAf have been falling gradually to nearly zero. In recent years, despite the fact that national leaders could impose tariff-rate quotas on cotton after a certain volume had been imported, trade officials essentially left the level of imports in most years to be determined by the market.

Livestock and horticultural commodities. With the exception of milk, the patterns of distortions to China's livestock and horticultural sectors are quite similar (Table 7.4). Between 1980 and 1993, there was heavy implicit taxation on pork and vegetables. In part, as noted by Huang et al. (2004), this situation was created by China's grain-first policy. Although China can produce livestock and horticultural products competitively, producers were encouraged neither to produce nor to export these commodities on a large scale. This was due, in part, to China's own barriers, such as quotas on exports into Hong Kong. Another part of the price gap shown in these figures reflects trade barriers facing China in export markets. While there were possibly grounds for some of the barriers (for example, foot and mouth disease is widespread in China), even if a claim was blatantly false it could not be adjudicated effectively since China was not then part of the WTO. As a consequence, China's livestock and horticultural producers produced commodities far below the world market price and were neither inclined nor able to increase exports into global markets.

Since the mid 1990s, the gap between domestic and world prices for livestock products has lessened, but the trends are not clear for the horticultural sector. Emerging markets and relaxation of grain-first policies (often called agricultural structural adjustment policies inside China) allowed producers to greatly expand livestock and horticultural production in large part to meet the rising demand inside China (Rosen et al. 2004). At the same time, China's accession to the WTO and the appearance of an export-oriented segment of the livestock and horticultural industries has increased the interest in and feasibility of participating in international markets. In response, the price gap measures have been falling. It should be noted, however, that the NRAf are all still negative. If anything, China's presence in global food markets has given rise to more stringent rules and regulations on the importation of livestock and horticultural commodities from China. 
Table 7.4 Nominal rates of assistance for farmers (NRAf) for livestock and horticultural sectors in China, 1980-2005 (per cent)

\begin{tabular}{lccc}
\hline & $1980-93$ & $1994-2001$ & $2002-05$ \\
Milk & 73 & 17 & 24 \\
Poultry & -11 & -28 & -19 \\
Pork & -57 & -19 & -8 \\
Vegetables & -50 & -22 & -23 \\
Fruit & -19 & -29 & -28 \\
\hline
\end{tabular}

Source: Authors' estimations.

Milk and sugar. The story for milk and sugar is in some senses the opposite of that for livestock and horticultural commodities. During the 1980s and early 1990s, the NRAf for milk and sugar were positive and large (Table 7.3, Row 3 and Table 7.4, Row 1). Those for milk averaged 70 per cent in the period 1980-93. Those for sugar were above 33 per cent in the same period. After the mid 1990s, protection was lowered, and NRAf for milk and sugar fell (to about 20-25 per cent in 2002-05).

\section{Conclusions and implications}

The main finding of our chapter is that the nature of policy intervention in China's agriculture has changed dramatically in the past 25 years, transforming the agricultural sector from one characterised by high distortions to one that is relatively liberal and more integrated into the world market. In the 1980s and early 1990s (or the early reform period), there were distortions in external and domestic policies that isolated domestic producers and consumers from international markets. Importantly, during the early reform period, domestic marketing and pricing policies served to make the prices that domestic producers and consumers faced almost independent of the effects of trade policy. Because of this-even in the case of an exportable commodity, such as rice, a commodity that enjoyed little protection at the border from tariffs (meaning that the international and the free-market prices of rice were nearly identical)—domestic pricing and marketing policies did not allow producers to reap the profits from international-level prices and instead forced farmers to sell much of their surplus to the state at an artificially low price. Hence, domestic policies levied a tax on farmers even though there was little protection 
at the border. Similar dynamics characterised importable commodities such as wheat and soybeans where, despite fairly high rates of protection from trade policies, producers were receiving much less protection than they would have had there been a free domestic market for the importable commodities-while consumers were being taxed implicitly.

In contrast, since the early 1990s (the late reform period), the liberalisation of domestic markets has reduced the distortions from domestic policies (as the market has gradually replaced the state as the primary mechanism for allocating resources and has become the basis of farmer production and marketing decisions). At the same time-especially in the case of importable commodities - trade policy has become more liberalised, with distortions from border measures falling substantially. As a result, we find that in recent years (that is, since China jointed the WTO at the end of 2001), China's agriculture is much less distorted in two ways. First, the differences between international and domestic market prices have narrowed considerably for many commodities due to trade policy liberalisation. Second, the elimination of domestic policy distortions means that when trade liberalisation allows for the increased import or export of agricultural commodities, prices in China's domestic market change, directly affecting farmers.

Despite the finding that considerable liberalisation had occurred due to reforms in domestic and external policies, distortions to agriculture remained in the mid 2000s - 25 years after the beginning of reforms. In some cases, these remaining distortions arise from tariffs on importable commodities and the non-tariff trade barriers of other countries on China's exportable commodities. While low in international comparisons, China is still providing a degree of protection for a number of importable commodities (for example, maize, sugar and milk).

With this analysis, we have shown that China's agricultural economy has become one of the least distorted in the world. Clearly, the combination of domestic marketing reforms and international trade liberalisation has greatly freed up the decision-making environment for producers. In such an environment, phenomena such as rapid structural change from grain to more labour-intensive commodities and the rise of a horticultural and livestockbased export economy become more understandable. When farmers face less distortion they tend to move into those commodities in which they have a comparative advantage. 


\section{References}

Anderson, K., Martin, W., Sandri, D. and Valenzuela, E., 2006. Methodology for measuring distortions to agricultural incentives, Working Paper, Development Research Group, World Bank, Washington, DC.

Huang, J. and David, C.C., 1995. 'China's agricultural policy', report submitted to Food and Agricultural Organization of the United Nations, Rome (unpublished).

Huang, J. and Ma, H., 2000. 'International comparison of agricultural prices', International Trade, 10:20-4.

Huang, J., Liu, Y., Martin, W. and Rozelle, S., 2007. Distortions to agricultural incentives in China, 1981 to 2005, Working Paper, World Bank, Washington, DC.

Huang, J., Rozelle, S. and Chang, M., 2004. 'The nature of distortions to agricultural incentives in China and implications of WTO accession', World Bank Economic Review, 18(1):59-84.

Huang, J., Rozelle, S. and Wang, H., 2006. 'Fostering or stripping rural China: modernizing agriculture and rural to urban capital flows', The Developing Economies, XLIV-1:1-26.

Martin, W., Huang, J. and Rozelle, S., 2006. Exchange rates and agricultural distortions in China's agriculture, 1981 to 2004, Working Paper, World Bank, Washington, DC.

Ministry of Agriculture, various years (a). China's Agricultural Yearbook, various issues, China Agricultural Press, Beijing.

- - , various years (b). China Agricultural Development Report, China Agricultural Press, Beijing.

Ministry of Commerce, various years. China Foreign Trade Yearbook, various issues, China Foreign Economic and Trade Press, Beijing.

National Bureau of Statistics of China (NBS), various years (a). Statistical Yearbook of China, China Statistical Press, Beijing.

- - , various years (b). China Yearbook of Agricultural Price Survey, China Statistics Press, Beijing.

National Development and Reform Commission (NDRC), various years. Agricultural production cost and revenue materials compilation, Price Department, China Statistics Press, Beijing.

- - , (various years) National major commodity (service) price monitoring data compilation, Center for Price Monitoring, National Development and Reform Commission, Beijing (unpublished).

Office of Tariff Regulation, State Council, 1996-98. Import and Export Tariff Regulation of the People's Republic of China, 1996, 1997 and 1998, Law Press, Beijing. 
-—, 2005. Import Tariff and Export Tariff Rebate Compilation, 2005, Economic and Scientific Press, Beijing.

Orden, D., Cheng, F., Nguyen, H., Grote, U., Thomas, M., Mullen, K. and Sun, D., 2007. Agricultural producer support estimates for developing countries: measurement issues and evidence from India, Indonesia, China, and Vietnam, Research Report, No. 152, International Food Policy Research Institute, Washington, DC.

Organisation for Economic Co-operation and Development (OECD). OECD PSE/CSE database.

- -, 2005. OECD Review of Agricultural Policies: China, Organisation for Economic Co-operation and Development, Paris.

Park, A., Jin, H., Rozelle, S. and Huang, J., 2002. 'Market emergence and transition: arbitrage, transition costs, and autarky in China's grain market', American Journal of Agricultural Economics, 84(1):67-82.

Rosen, D., Huang, J. and Rozelle, S., 2004. 'Roots of competitiveness: China's evolving agriculture interests', Policy Analysis in International Economics, Vol.72, June 2004, Institute for International Economics, Washington, DC.

Rozelle, S. and Huang, J., 2004. China's maize economy: supply, demand and trade, Report for the United States Grains Council, Beijing.

—_, 2005. China's soybean economy: supply, demand and trade, Report for the American Soybean Association, Beijing.

Rozelle, S., Park, A., Huang, J. and Jin, H., 2000. 'Bureaucrat to entrepreneur: the changing role of the State in China's transitional commodity economy', Economic Development and Cultural Change, 48(2):227-52.

Sicular, T., 1988. 'Plan and market in China's agricultural commerce', Journal of Political Economy, 96(2):283-307.

Wang, D., Rozelle, S. and Huang, J., 1999. The impact of procurement quota on agricultural production in China's agriculture, Working Paper, Center for Chinese Agricultural Policy, Chinese Academy of Agricultural Sciences, Beijing.

\section{Acknowledgments}

The authors are grateful for helpful comments from workshop participants and for funding from the World Bank Trust Funds provided by the governments of Ireland, Japan, the Netherlands (BNPP) and the United Kingdom (DFID), and the Chinese Academy of Agricultural Sciences (KSCX2-YW-N-039). 


\section{Table A7.1 Raw numbers for exchange rate analysis, China, 1980-2005}

\begin{tabular}{|c|c|c|c|c|c|}
\hline Year & Official rate & $\begin{array}{l}\text { Secondary } \\
\text { market rate }\end{array}$ & $\begin{array}{c}\text { Retention } \\
\text { rate }^{a}\end{array}$ & $\begin{array}{l}\text { Discount to } \\
\text { secondary } \\
\text { market rate }\end{array}$ & $\begin{array}{c}\text { Estimated } \\
\text { equilibrium } \\
\text { exchange rate }\end{array}$ \\
\hline 1980 & 1.50 & 1.95 & 0.20 & 1.95 & 1.95 \\
\hline 1981 & 1.71 & 2.05 & 0.20 & 2.05 & 2.80 \\
\hline 1982 & 1.89 & 2.27 & 0.20 & 2.27 & 2.80 \\
\hline 1983 & 1.98 & 2.39 & 0.20 & 2.39 & 2.80 \\
\hline 1984 & 2.33 & 2.69 & 0.20 & 2.69 & 2.80 \\
\hline 1985 & 2.94 & 3.05 & 0.25 & 3.05 & 2.95 \\
\hline 1986 & 3.45 & 4.03 & 0.25 & 4.03 & 3.81 \\
\hline 1987 & 3.72 & 4.40 & 0.44 & 4.40 & 5.29 \\
\hline 1988 & 3.72 & 6.50 & 0.44 & 6.50 & 5.79 \\
\hline 1989 & 3.77 & 6.60 & 0.44 & 6.60 & 4.94 \\
\hline 1990 & 4.78 & 6.60 & 0.44 & 6.60 & 5.44 \\
\hline 1991 & 5.32 & 6.60 & 0.80 & 6.60 & 5.84 \\
\hline 1992 & 5.52 & 6.92 & 0.80 & 6.92 & 7.12 \\
\hline 1993 & 5.76 & 8.28 & 0.80 & 8.28 & 8.41 \\
\hline 1994 & 8.62 & 8.70 & 0.80 & 8.70 & 8.69 \\
\hline 1995 & 8.35 & n.a. & n.a. & n.a. & 8.35 \\
\hline 1996 & 8.31 & n.a. & n.a. & n.a. & 8.31 \\
\hline 1997 & 8.29 & n.a. & n.a. & n.a. & 8.29 \\
\hline 1998 & 8.28 & n.a. & n.a. & n.a. & 8.28 \\
\hline 1999 & 8.28 & n.a. & n.a. & n.a. & 8.28 \\
\hline 2000 & 8.28 & n.a. & n.a. & n.a. & 8.28 \\
\hline 2001 & 8.28 & n.a. & n.a. & n.a. & 8.28 \\
\hline 2002 & 8.28 & n.a. & n.a. & n.a. & 8.28 \\
\hline 2003 & 8.28 & n.a. & n.a. & n.a. & 8.28 \\
\hline 2004 & 8.28 & n.a. & n.a. & n.a. & 8.28 \\
\hline 2005 & 8.19 & n.a. & n.a. & n.a. & 8.19 \\
\hline
\end{tabular}

a The proportion of foreign currency sold by all exporters at the parallel market rate.

Sources: For the official rates, National Bureau of Statistics of China, various years (a). Statistical Yearbook of China, various issues from 1981 to 2006, China Statistical Press, Beijing. National Bureau of Statistics of China, various years (b). China Yearbook of Agricultural Price Survey, various issues, China Statistics Press, Beijing; For the secondary market rates, Huang and David 1995. For the estimated equilibrium exchange rates, on the exchange rate methodology, see Anderson, K., Martin, W., Sandri, D. and Valenzuela, E., 2006. Methodology for measuring distortions to agricultural incentives, Working Paper, Development Research Group, World Bank, Washington, DC; Huang, J., Liu, Y., Martin, W. and Rozelle, S., 2007. Distortions to agricultural incentives in China, 1981 to 2005, Working Paper, World Bank, Washington, DC. 